\title{
Justice and the Missional Framework Document of the Dutch Reformed Church
}

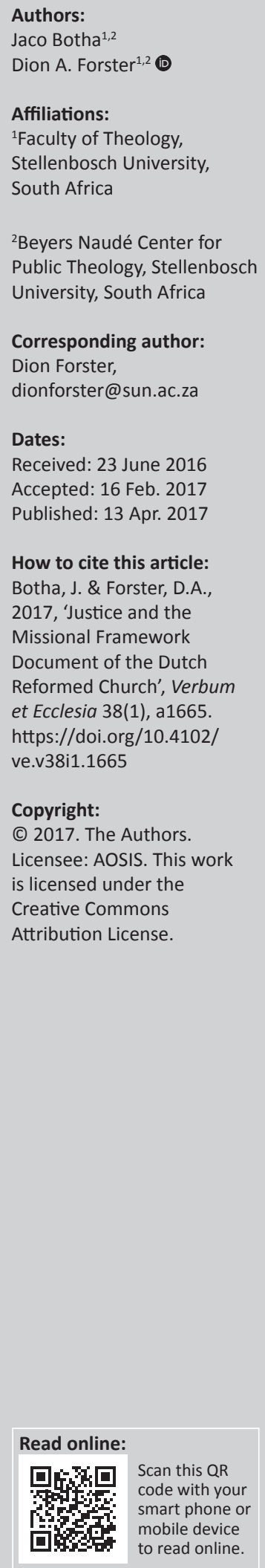

This article engages with the Missional Framework Document of the Dutch Reformed Church (DRC) from the perspectives of solidarity with the poor and justice for South African society. The democratic South Africa continues to face significant socio-economic problems and an increasingly dissatisfied population. In the light of this, the article presents an introductory conversation with the Missional Framework Document in order to ask whether it offers an adequate response to South Africa's current contextual challenges. The lens through which this article will engage the Framework Document is the theological paradigm of justice, specifically the theory of justice presented by Nicholas Wolterstorff as well as some important contributions from contemporary South African scholars who advocate for a theology from the margins of society. It is contended that the DRC remains a predominantly white middle-class church. This social, economic and political location has an impact on the missional theology of the church as expressed in the Framework Document. Hence, we engage with the Missional Theology of the DRC by means of a paradigm that operates from the 'underside' or the economic, political and social 'margins' of South African society. We argue that any missional theology aimed at furthering God's Kingdom in South Africa at present must develop in community with the marginalised majority of the nation. The critical engagement with the Framework Document will be done by sketching a theological landscape where current contextual realities are brought into relief against a kairos moment on which the efficacy of this church's mission, indeed its public work and witness, is being called into question.

Intradisciplinary and/or interdisciplinary implications: This interdisciplinary study in Systematic Theology and Ethics engages the missional theology found in the Missional Framework Document of the Dutch Reformed Church. Methodologically, the research advocates for a contextual engagement with the missional theology proposed by this important document. The outcome of this contextual theological consideration is an invitation for the Church to consider the ethics of justice as an important aspect of their approach to faithful Christian mission in the South African social, economic and political context.

\section{Introduction}

This article intends to reflect on the public work and witness of the Dutch Reformed Church (DRC), as expressed in its Missional Framework Document ${ }^{1}$ (Framework Document), in relation to the contextual realities of South Africa at present. It aims to do so by facilitating a theological engagement between the Framework Document and the current contextual challenges in South Africa within the framework of a theology of justice ${ }^{2}$. Because the DRC sees the Framework Document as the vanguard of both its missional theology and the church's identity ${ }^{3}$, reflecting on it through the lens of justice proposes the need for a conversation around the Church's mission and ministry in these critical times in South Africa. This is all the more important because the Missional Framework Document is presented as a significant cornerstone of the DRC's identity ${ }^{4}$

1.Since the Missional Framework Document is a substantial document in its own right, we will not be able to offer an overview of the whole document and its contents here. Moreover, our intension is to engage the document as we perceive it from the hermeneutic perspectives which are developed in this article. We do recognise that different readings and perspectives of the Framework Document are possible and would encourage the reader to read the document for themselves.

2.The premise of this article is to focus on the missional theology in the Missional Framework Document. We are cognisant of the fact that the Church has numerous policy documents that we will not address directly in our argument. The principle we used in constructing our engagement with the Missional Framework Document is that important issues, or necessary theological concepts, from other
policy documents would have been touched upon or referenced by the authors of the Missional Framework Document. The fact that justice is not sufficiently and directly addressed in this document is what concerns us. Hence, although the church may have other justice is not sufficiently and directly addressed in this document is what concerns us. Hence, althoug
documents on justice and service, it is a concern that these are not reflected in this policy document.

3.Van der Merwe (2014:204-209) traces the narrative of Missional Diaconate within the DRC. He sees the 2013 synod as a watershed moment in the missional identity of the DRC. It is at this synod that the Framework Document was accepted and heralded in a new era in the DRC's history.

4.For more focussed comments on the nature and trajectory of missional ecclesiology within the DRC, see Niemandt (2010, 2014). 
moving forward. The Framework Document does, however, form part of a long and complex history of missional thought within the DRC and must also be understood against that backdrop.

\section{Background to the Missional Framework Document}

As the Framework Document correctly points out, the DRC (together with every other church in South Africa) functions in a changing context. This has necessitated that the denomination thinks critically and creatively about its mission and ecclesiological identity. The document, however, does not function as a new beginning for missional thought in the DRC. Rather, it stands as a contribution in a long history of missional thought and praxis. Willem Saayman, in his book Being Missionary Being Human, gives a brief, but thoughtful, reflection on the 350-year missional history of the DRC. Saayman describes the missional history of the DRC in 'four waves' beginning in 1779 with the first wave (Saayman 2007:15-39) and ending with the current 'fourth emerging wave' (Saayman 2007:100-117) which started in 1990. It is within this fourth wave that the Missional Framework Document develops as part of the missionary evolution of the DRC (Niemandt 2010:93-96). This evolution is also traced and commented ${ }^{5}$ on by Van der Merwe (2014:83-89) who traces the missional trajectory of the DRC in its context of the traumatic awakening from endorsing to rejecting apartheid. Thus, the document should be understood not only within the broader narrative of missional theology within the DRC as a church that has only recently come to terms with life beyond apartheid, but more specifically within the context of the democratic South Africa.

There is some debate on the nature and texture of this fourth wave, but what is certain is that at the start of the democratic age of South Africa, the DRC (together with all South African churches) entered into a new era which would ask deep questions about the identity and calling of the Church. Saayman (2007:100-108) points out the traumatising nature of democratic change for all South Africans' (specifically the Afrikaners') self-understanding ${ }^{6}$. This time of change - post 1994 South Africa - is what creates the context within which the Framework Document finds its meaning. The purpose of this discussion is thus whether or not the Framework Document offers an accurate, theologically sound and contextually sensitive response to the changing landscape of South Africa.

5.Van der Merwe (2014) argues parallel to this article in Met Woord en Daad in Dien van God: Die Diakonaat van die NG Kerk in Post-Apartheid Suid-Afrika that a new awakening of the DRC is at hand specifically regarding the missional diaconate of the church and its role and calling towards the poor and marginalised. Van de Merwe (2014:207-208) traces the roots of the Framework Document to a discussion within the DRC on what its role should be in a post-1994 South Africa. The Framework Document must therefore be understood as a culmination of various other reports and documents on the nature and role of the DRC which were collected and represented in this one document.

6.Van der Merwe (2014) does well to articulate the scale of the trauma encountered by the DRC and its members with the dawn of the democratic South Africa. One must be careful not to underestimate these social and political changes as well as must be careful not to underestimate these social and political changes as well as the . This bing said, pinning down the chan the DRC. This being said, pinning down the changes and shifts in theologicalthinking only to social and political movements is also unwise, because the development of theology both within the DRC and in the broader reformed tradition also plays pivotal role in such developments.

\section{Reality and kairos: The Dutch Reformed Church in a democratic South Africa?}

South Africa's current situation is one of crisis. It is within this setting that the Missional Framework Document aims to perpetuate and support hopeful missional communities in South Africa. The 2014 Institute for Justice and Reconciliation Barometer Report (IJR report) paints a painful picture of life 20 years into democracy. In the report, it is evident that aspects of reconciliation and race relations, as well as the perception of the past, are deeply negative. As an example, the report suggests that only $50 \%$ of white people feel that apartheid oppressed the majority of South Africans and only $33.4 \%$ of white South Africans feel that apartheid resulted in the poverty of many black South Africans (Institute for Justice and Reconciliation 2014:32). The 2015 document underlines the remaining segregation, where $61.4 \%$ of respondents feel that race relations have either stayed the same or deteriorated since 1994 (Institute for Justice and Reconciliation 2015:1). The 2015 document further states that $67.3 \%$ of the population have little or no trust in people of other race groups (Institute for Justice and Reconciliation 2015:1). However, there are some positive aspects: The 2014 document states that association by socialisation across races has improved from 1 out of 10 in 2003 to 2.4 out of 10 (Institute for Justice and Reconciliation 2014:23). This increase might suggest a positive upward curve, but it must be read within the context of a struggling nation still battling with its past as the recent confrontations $^{8}$ and debates regarding statues and colonial influence suggest. Moreover, one must understand these findings within the context of the current upsurge in racial tensions that has been expressed on social media'. As a whole, the IJR report conveys that South Africa is not a reconciled nation; South Africans have not moved past the pain and anger that separated their parents and they still cling to their segregated and separated identities. In light of the above, the questions to be asked are whether DRC sees itself as a church which aims to promote relationships that reflect Christ and His kingdom and whether the Missional Framework Document promotes concepts of justice and reconciliation among all people in South Africa?

Equally important is the issue of income and economic equality. South Africa has one of the world's largest gaps between rich and poor ${ }^{10}$. The World Bank estimated that in

7The term 'democratic' is specifically chosen by the authors rather than using the term 'post-apartheid South Africa'. The authors contend that the use of the term 'post-apartheid' South Africa is premature in many senses. Although in some senses South Africa is in a post-apartheid dispensation, in many other ways that are most connected with daily experience, it is not (e.g. South Africans remain segregated along economic, class and racial lines to an extent that is more problematic in 2016 than in 1994).

8.For more on the local congregation and its ability to impact society in terms of restitution and reconciliation, see Bowers du Toit (2012:210).

9.The recent upsurge in racist comments on social media has made its way into the international media. The comments made by individuals such as Penny Sparrow might suggest that South Africa is currently feeling the effects of suppressed emotions not dealt with at the start of its democratic era. For an insightful consideration of this, see Lind (2016).

10.South Africa has a Gini index of 65 as measured by the World Bank: http://data. worldbank.org/country/south-africa?view=chart 
2011 South Africa had a poverty headcount ratio of $53 \%,{ }^{11}$ underlining the fact that most of South Africa lives, at least to some extent, in poverty. This national poverty line, ${ }^{12}$ as presented by the Stats SA 2011 census, presents a dark reality. Twenty-seven million people are living below the South African poverty line ${ }^{13}$ on less than R26 per day. More alarming is the 10.7 million people ( $22 \%$ of the total population) that survive on less than R11 per day (Stats SA 2014:7-9). Writing on the public nature of the church as a bearer of hope for South Africa, Forster (2015) expounds the current political, social and economic realities facing South Africa after 20 years of democracy. His findings underline that South Africa is indeed a better country today than at the birth of our democracy; however, it must be clearly understood that we are far from where we can be, and ought to be ${ }^{14}$ (Forster 2015:13-20). These figures, and Forster's comments, might well prove to reflect an economic context that shifted dramatically in 2016 as the South African currency, the Rand, faced massive depreciation, commodity prices fell, and national drought impacted the economy, further widening the income inequality gap among South Africans ${ }^{15}$. It is into this context that the Church of South Africa is called to be a bearer of hope, and so also the context in which the Missional Framework must function as one source of missional and prophetic guidance for the Church.

\section{Kairos}

The message that the church is called to bear is a message of hope. The location of this hope stems from a deep solidarity with those who are suffering and who are particularly predisposed to the evils and injustices of the world (Migliore 2004:338) ${ }^{16}$. Such solidarity stems from a careful act of mutual discernment focused on the question 'what does God require of us today in order to partake in the emerging Kingdom of God?'. This is an attempt to respond faithfully and appropriately to the particular needs and concerns of a time and context, that is, kairos. Kairos is understood as an opportunity given by God demanding response, which can be only one of acceptance or non-acceptance (Brown 1990:3). One must understand that awareness of the kairos moment (understood here in the context it was developed in the Kairos South Africa documents of the 1980s) of God begins with analysing the current situation which Brown identifies as a situation of oppression, suffering or pain (Brown 1990:10).

11.Poverty headcount ratio is measured in national poverty lines: hittp://data worldbank.org/country/south-africa

12.Stats SA presents three poverty lines: The first being people living on less than R26 per day, the second being people who love on less than R16.50 per day and the third people living on less than R11 per day.

13.This poverty line is defined by Stats SA as minimum of food and non-food items that a person needs to survive per day. For a graphic representation on these statistics visit: http://mg.co.za/data/2015-02-05-infographic-poverty-in-south-africa

14.Also see De Gruchy (2013:196) for a further theological interpretation of postapartheid South Africa.

15.The worst drought in recent history has resulted in estimates of $30 \%$ of maize not being planted in the 2015 planting season resulting in the maize price doubling in one year. See Dan Cancian's article in the International Business Times dated 18 January 2016 for a discussion of the implications of this drought: http://www. ibtimes.co.uk/south-africas-economy-under-threat-by-weak-rand-worst-drought-
record-1538608

16.Bosch (2011:520) is adamant that Christion hope is the culmination of the past, the present and the future thus taking seriously the 'penultimate' but in creative tension with the resurrected future as proclaimed by Christ.
The meeting point between hope and kairos, at least for the church, is to be found in the midst of the suffering and the marginalised in society. Both kairos and hope ask of the church to be deeply aware of those it is called to serve (which includes the marginalised). Sadly, it would seem that this encounter has been largely inadequately undertaken. Some assume that the task is complete when the church, its members or officers have developed a theology about the poor. Others have assumed that the church has fulfilled its mandate when it professionalises its diakonia through specialist task teams or justice initiatives. In both of these approaches, the outcome is the objectification of the poor and the limiting of proximity between the broader church and the communities it serves. An effect of this often is the establishment of unequal, and even abusive, power imbalance. As will be shown, there are tendencies of such an approach evidenced in the Missional Framework Document.

\section{Understanding justice from below}

On 16 August 2012, 34 mine workers were shot by police in a conflict between Lonmin's Marikana mine management and their workforce. The leader of the striking miners, Mgecineni Noki, died in a manner that has been likened to the Sharpeville ${ }^{17}$ of the new South Africa ${ }^{18}$. A combination of big business seeking profit at the expense of minimum wage workers, increasingly radicalised trade union involvement, a militarised police and the misuse of political power resulted in a boiling pot of violent and blatant murder as uncovered by the 'Farlam Commission'19. Mgecineni Noki's life of struggle and his inhumane death have come to serve as a symbol for all those who have lost their lives in such conflicts, as well as those who are still held captive by an unjust social, political and economic system. What is of grave concern is that there are many who are aware of the existence of injustice yet fail to act upon their knowledge. These sins of omission have come to be prevalent in many spheres of South African society as well as within the church. The churches in South Africa do engage the oppressed and the oppressors; however, in large measure the churches that occupy social prominence and power in contemporary society have tended to be removed from the most vulnerable members of society.

As mentioned above, South Africa is currently in a phase of vast inequality with brutal repercussions, specifically for those on the underside of power. This article intends to critique the underlying theological currents of the Missional Framework Document ${ }^{20}$ through the lens of the marginalised,

17.For more information on this, see Swart and Rodny-Gumede (2015).

18.For a more nuanced perspective of different political role players and their reactions towards the Marikana massacre see the news 24 article Marikana shooting like Sharpeville available at http://www.news24.com/SouthAfrica/News/ Marikana-shooting-like-Sharpeville-20120817

19.It is officially named the Marikana Commission. See http://www.marikanacomm. org.za/documents.html

20.One of these currents which influenced the Framework Document is the DRC's Season of Listening (paragraph 13) in which the Framework Document locates itself. This document must then be read within a broader narrative of a denomination engaging in missional theology from various angles. This season of listening is understood by the Framework Document in order to find and discern 'new expressions of church' rather than being specifically focussed on listening to the marginalised (Dutch Reformed Church 2013:11, 13). 
illustrated in stories like those of Mr. Noki. This is not done to overly politicise a theological argument, but rather to ask whether the DRC has fully grasped the current social, political and economic realities in which its missional mandate must take root. Failing to do so will inevitably lead to a church more interested in keeping its middle-class status than being a vehicle of hope $\mathrm{e}^{21}$ in a broken world.

This upsurge in liberation thinking contended to be part of the kairos of that the South African church is facing. However, it is not confined to this country. Recent statements made by a growing number of theologians, including Pope Francis, warn the wealthy and the privileged members of society of the implications of ignoring the plight of the poor. These statements seem to echo the calls of Liberation Theology in the 1960s which has since been developed into a formidable paradigm for engaging with unjust structures and actors in society by advocating for the marginalised.

One contemporary theologian who is advocating for the theology from the margins is Joerg Rieger. His theology extensively advocates for viewing theology from the perspective of the marginalised and taking seriously the biblical call to stand in solidarity with the poor. This is a contemporary recapturing of one of the cornerstones of Liberation Theology. Liberation Theology helped to focus the theological discourse of the 20th century on the needs and concerns of those on the economic underside of history. Moreover, it also helped to give rise to other 'subversive' theologies from the margins such as feminist discourses, African and Asian discourses, queer theologies and so on (prominently in recent DRC history is \#liefdeisliefde theological movement) (Rieger 2003:3).

It is the view of the authors that the theology contained within the Missional Framework Document is close to what Rieger (1998:19-22) names as 'liberal theology ${ }^{22}$. The viewpoint of liberal theology is traced by Rieger to Schleiermacher who perpetuated the notion of God being in support of modern society. Both powers, God's and modern society's, are understood as being supportive of one another. This form of liberal theology is one that supports and nuances the modern individual's relationship (Rieger 1998:21) with God and that leads, subtly, to a theology of power. The criticism Rieger levies against liberal theology is that it fails to understand its natural tendency to lean towards the politically and socially powerful, therefore excluding those on the margins (Rieger 1998:21). In such a theology, God is the God of progress, innovation, development, modernisation and well-orchestrated pension funds. Lost is the God of the cross, suffering in poverty for the liberation of the whole

21.For an explanation of why the phrase 'vehicle of hope' is used, see Jaap Durand's sermon entitled The Church: Vehicle of Hope in Du Toit (2014:175-178).

22.Rieger (1998:14-15) understands Liberal Theology as having its origins in the Enlightenment. Starting from Descartes and finding theological roots in Schleiermacher, Rieger argues that liberal Theology plas theiermacher, Rieger argues that Liberal Theology places at the center of reason the subjective reality of the modern person. Schleiermacher argues that (objective) the tf self (Rieger 1998.15). The result is that for Rieger, Liberal Theology places the modern self at the center of history and thereby discards the voices and place of the marginalised. of creation. We are not arguing, by any means, that this is the major trajectory of the Framework Document. However, one can see traces of liberal theology within the document because it argues not from the perspective of the marginalised, but from the perspective of a powerful, predominantly white church. The Missional Framework Document rightly argues for the church to be in 'proximity' (Dutch Reformed Church 2013:8) to the poor and to walk 'in the other person's shoes', but it does not acknowledge the power differences between the itself and 'the other'. Therefore, it is seemingly unaware of the power dynamic operating between the DRC and the most marginalised in South African society.

Nicholas Wolterstorff is another contemporary theologian who advocates for a theology from the perspective and placement of the marginalised in society. Wolterstorff's departure in his theory of justice starts not from the traditional philosophical frameworks, in comparison with the philosopher John Rawls, who argues from an existential viewpoint ${ }^{23}$. Rather Wolterstorff posits his thought in a much older tradition - the tradition of the Biblical writers themselves (Wolterstorff 2013:7). Wolterstorff contests the modern (contemporary) viewpoint that the rights of people are implanted by institutions or constitutions. Rather, he argues that humans are assigned rights at creation, that is, the rights of the human person stem from their created dignity. The impact that this view has on theological reasoning is significant. In such a perspective, humans cannot be given or accorded rights; rather, human rights exist as part of them being created in the Imago Dei. This view has far-reaching implications, specifically within contexts of injustice where inherent human rights are violated. Wolterstorff (2013:32) argues for viewing justice from the perspective of the marginalised in order to propagate rights for those who cannot 'earn' rights as easily as those on the powerful end of the social spectrum.

The notion of 'earned rights' as bestowed upon people by institutions has had devastating effects on persons and society. For example, in the 1930s, the German Reich sought to bestow more rights on Aryan Germans than on Jews. Dietrich Bonhoeffer, responding to the German Reich's publication of the Law for the Restoration of the Professional Service of April 7 1933, is deeply critical about this perspective. In his reflection, Bonhoeffer cites the state's mandate to uphold order in society that protects all its citizens and not to engage in immoral actions such as the segregation of persons by race (Green \& Dejonge 2013:370-378). Bonhoeffer argues that where such an unjust abuse of state power takes place, ${ }^{24}$ it is the role of the Church to politically engage the state in order to expose the injustice.

This intrinsic right or value accorded to the human person is what Wolterstorff describes as rendering to a person his or

23.The aim of this article is not to fully extrapolate the complexities of the different strands of philosophical thought on justice, but rather to bring into focus a specific philosophical ideal, or perspective, put forth by Wolterstorff.

24.Bonhoeffer is adamant that only in times of deep immoral actions by the state, is the Church to politically engage it in order to protest injustice (Green \& Dejonge 2013:374) 
her $i u s^{25}$ (Wolterstorff 2013:42). Ius is therefore the means to articulate that which is needed to embed justice in a community. Wolterstorff says such 'primary justice' is a situation which is present when a person has the ability to enjoy something he or she has the right to (Newbigin 1995:110) (e.g. a right to proper education) (Wolterstorff 2011:86). This leads Wolterstorff to argue for the relational inherency of justice among persons and in society (Wolterstorff 2011:90). By relational inherency, Wolterstorff means to connect a just society with the community which finds rights in the nature of humanity and not in objective rights imported from outside the community. When one considers these aspects as a whole, the just society is one in which the culmination of relationships allows persons to enjoy that which they have an inherent right to.

Wolterstorff (2013:110-111) articulates the Christian view of human life in terms of the Imago Dei ${ }^{26}$ (Wolterstorff 1983: 78-79) and this, he argues, is what gives us our value and worth ${ }^{27}$. The implication is that no human being can lose his or her worth before God. One's value can, however, be disavowed by individuals or institutions by not rendering to a person what they are worth. It is intrinsic in our being, yet it remains vulnerable to human action. If this argument is followed, human inaction in instances of injustice can also be the perpetuation of injustice, because it does not render what is just and in so doing disavows a person's worth. Thus, the question is not in whether each person has equal rights (in law, as an example), but rather in whether we (as the church) acknowledge those rights and live the realisation of those rights for every person in society?

In such a context, one might envision a Marikana where the church (and here specifically the DRC) would have been in a relational position with the striking marginalised to advocate for their intrinsic rights ${ }^{28}$ as part of the Imago Dei. These intrinsic or primary rights, if acknowledged by the church, become a platform on which the dignity of human beings is explicated and could have been advocated for in relation to the powerful and their rights (in this case, the Lonmin mining company and the political authorities). This would undoubtedly emulate the notion of a confessing church ${ }^{29}$ in times of trauma or, to state it theologically, in times of kairos.

An example of such a reaction to injustice can be seen in the actions of Beyers Naudé in his plea in May 1989 at

25.lus is the term Wolterstorff used to describe the inherent right which is due to person. The term is first used by the 3rd century Roman jurist Ulpian who understood a just society as one where every person is rendered his or her ius (Wolterstorff 2011:85).

26. Wolterstorff bases his argument of the Imago Dei on that of Calvin in his reflections on poverty where Calvin insists that the great unifier is that all persons share the image of God (Wolterstorff 1983:78).

27.It is important to note that Wolterstorff, in his book Journey towards Justice, gives an articulate argument on the presence of natural rights in the early church fathers. He traces the occurrence of natural rights from the early church fathers to the core of the Old Testament, arguing that this concept is the very basis on which early Christian doctrine was built (Wolterstorff 2013:65-78).

28.One must be careful not to oversimplify the discussion regarding employee rights in South Africa. What this article does aim for is to present a platform of acknowledging the very basic of human rights, such as the right to life and the right to dignity, which were violated at various levels in the Marikana tragedy.

29.For this and other examples of the Confessing Church in the South African context, see De Gruchy and Villa-Vincencio (1983:75-93).
The Hague. At the annual shareholder meeting of the multinational corporation, Royal Dutch Shell, Naudé asked Royal Dutch Shell to remove itself from South Africa following the company's cooperation with and support of the apartheid regime (United Nations General Assembly 1990). In discussing the violation of rights, it is also worth considering Wolterstorff's take on the anger and emotion that builds up among the marginalised - he contends that this also requires attention.

Together with primary rights, Wolterstorff also notes the existence of 'reactive justice'. This, Wolterstorff argues, is the notion of the right to anger after being wronged (Wolterstorff 2013:23). Interestingly, the distinction between primary justice and reactive justice, and the impact thereof, is mentioned within Wolterstorff's lived experience of apartheid South Africa. He describes his own experience in South Africa as one where he became aware that the need of the oppressed black and brown people of South Africa was not primarily reactive justice (i.e. to retaliate or render retribution against their oppressors) but primary justice (i.e. for them to be given what is due to them as part of their inherent worth) (Wolterstorff 2013:23-24). The result of this experience is Wolterstorff's move from a top-down to a bottom-up theory of justice.

By 'bottom-up' Wolterstorff means to move to an understanding of justice from the viewpoint of the wronged rather than from a detached moral ideal ${ }^{30}$. He expounds the logic and implications of this view of justice when writing about the connection between love and justice (Wolterstorff 2011). He points out the merit of his argument as follows:

Justice is present in society when people enjoy the good to which they have rightful claim: protection against assault, freedom to worship as they see fit, sufficient food to live and work etc. Now the strong and powerful in society will generally be able to secure such goods on their own. Hence to find out whether a society is just, one must not look at the powerful but at the weak: Do the practises and institutions of the society secure to them the enjoyment of relevant goods? The test is not whether the economically powerful have enough to eat, but whether the economically powerless have enough. Justice is society's charter of protection of the little ones. (p. 97)

Consequently, in this schema, it is not the prerogative of those who have power to dictate what justice is needed, that is, the privilege of those yearning for justice or suffering injustice. In measuring and naming the injustices of the South African context, a lot can, and should, be said. Education, economic inequality, adequate housing, sanitation, security, violence, gender rights and many other aspects could be named as specific areas where justice is necessary. This is, however, not the place, and perhaps not even the prerogative of the authors, to do $\mathrm{so}^{31}$. What is apparent and needed is the

30.Albert Nolan (1988:63) notes that in the Bible, oppression is always described 'from below' as the experiences of those pushed down by an unjust system.

31.As stated above, the privilege of naming the injustices rests with the cries of the marginalised. Therefore, to discuss any injustices without first listening to the call 'from below' would not take seriously the argument of this chapter. The point is to, 'from below' would not take seriously the argument of this chapter. The point is to,
in relationships, listen to those cries from the oppressed, stand in solidarity with the oppressed and then act appropriately upon that call. 
call for primary justice to be heard from the margins, and for that call to be acted upon. If Wolterstorff's theory of justice is to be taken seriously, standing in solidarity with the 'little ones' is the only means to advocate for, and partake in, primary justice as a response to God's love for the poor (Wolterstorff 2011:97).

Solidarity is a key theological concept within this discussion ${ }^{32}$. The difference that starting from the perspective of the wronged makes is that one is confronted with the personal accounts of human beings whose worth is being denied (Wolterstorff 2013:156). Just as the crucified God is in solidarity with the poor, so too is the believer is called to be an advocate, not a bystander. The Christian disciple is called to be a part of the community that suffers. If Wolterstorff is correct in presuming that justice is central to God's will for creation, then justice is not incidental as a reaction to sin and brokenness. Rather, it is a prerequisite to the reign of God in creation. Thus, one could ask, what is the role of the Church in a context of injustice? One possible answer that this argument advocates is that the church, as partaking in the Missio Dei (as the Framework Document suggests), will have to adopt a position of solidarity with those who are suffering. The mission of God is in solidarity with persons and not only with the most recent trends in missional theology.

\section{Mission and the marginalised}

Because the Framework Document is a missional document aimed to promote and pursue the coming Kingdom of God, it is necessary to also include a missiological perspective on the marginalised.

The South African missiologist, David Bosch suggests that Schleiermacher pioneered the notion that all theology is contextual, and therefore, no theology is never 'suprahistorical' or 'supracultural' (Bosch 2011:432). Bosch suggests that such a contextual understanding of mission, as an ethical approach to the Missio Dei, highlights the following points. Firstly, since Schleiermacher, theologians have come to regard exclusively Western theology and philosophy with suspicion because of the West's tendency to work largely towards its own interests (Bosch 2011:434). Secondly, contextual models do not accept the world as an inert object which cannot change for the better (Bosch 2011:434), and thus, such a model pushes back on the philosophies that approach the world as something to be explained and not changed. Thirdly, Liberation Theology (Newbigin 1978: 102-134) is theology's commitment to the poor, facilitated a theological point of departing from orthopraxy and rather than mere orthodoxy (Bosch 2011:434). Fourthly, Bosch notes Barth's statement that theology cannot be done from a bird's eye view (i.e. only evaluating the world in its brokenness); rather, contextual missional theology requires 'theologizing credibly with those who suffer' (Bosch 2011:435). This point is of specific importance within the context of South African

32.Albert Nolan gives a contextual view of the crucified Christ as a symbol of God in solidarity with the poor. This, he argues, is the model for how Christianity is called to stand in solidarity with the oppressed: As God is in solidarity with the oppressed on the cross, so the church should be with those who suffer in the world. history and will be returned to at a later stage. Fifthly, doing theology in this perspective of contextual solidarity is seen as more important for the development of rigorous knowledge (Bosch 2011:435). However, as will be seen, doing theology does not replace knowing, it just re-orientates the process and reasons for the development of knowledge. Finally, contextual theology (in advocating orthopraxis and solidarity with the marginalised) calls for a hermeneutical circle where praxis is viewed as a primary task of theology and reflection as a secondary task (Bosch 2011:435).

One could argue that Bosch's contextual missiology is, to some extent, deeply influenced by Liberation Theology, ${ }^{33}$ thus placing huge emphasis on attending to the needs, concerns and perspectives of the 'other'34 (Bosch 2011:436). Liberation Theology accentuates praxis as the starting point of credible theology, which is in comparison with some other theologies which start from theory. Theology is therefore the critical reflection on historical praxis (Gutiérrez 2000:12-13). The result is that, from the perspective of a credible theology of mission, Bosch, citing Bonino, warns against the creation of global systematic theologies 'where everything fits into an all-encompassing and eternally valid system' (Bosch 2011:437). Bosch further contends that contextual missiology requires that the signs of the times, as stated above, are taking seriously (Bosch 2011:438-439). The implications of this statement require theologians to view history as part and parcel of God's salvation narrative. Hence, one need not only pay attention to current contexts but also has to consider history and the signs of God's work, will and expectations in the past (Bosch 2011:439).

Reading the signs of the times might be important for the formation of a contextual theology, but Bosch warns against over-emphasising this aspect because it is possible that these signs can be misread (Bosch 2011:439-440). He contends that the ambiguities connected with changing contexts and divergent views on history moves cause him not to take context as the 'sole authority for theological reflection' (Bosch 2011:441). Bosch therefore moves towards a view similar to that held by John Stackhouse, who argues for both praxis and theory (theoria). However, Bosch adds poesis as an existential ingredient which he equates with love ${ }^{36}$ (Bosch 2011:442). These three ingredients work together in a perichoretic way in order to holistically become a contextual missiology which can respond to a specific place and time by taking into

33.For a deeper and more insightful understanding of Bosch's connection with Liberation Theology and how that specific paradigm played a part within the South Liberation Theology and how that specific paradigm pl
African apartheid context, see Van Wyngaard (2013).

34.It must be noted that Bosch, although influenced heavily by Liberation Theology, advocates for an ecumenical cross-pollination of theology where Western theologians study Third World theologies and vice-versa. Thus, Bosch's argument is not based solely on insights from Liberation Theology, but it does feature in part of his argument to advocate for an ecumenical and global theology which should be used to create a contextually relevant missiology.

35. Bosch also sites Liberation theologian Mígues Bonino (1975:27-41) who states that in Scripture, it is the 'doers' who are the blessed as opposed to those who only know (Bosch 2011:435).

36.Stackhouse (1988:85; cf 104) (in Bosch 2011:441) defines poesis as the 'imaginative creation or representation of evocative images'. Although this does not translate into love, Bosch uses this term in order to describe the mystery and depth of awe into love, Bosch uses this term in order to describe the mystery and depth of awe
(Bosch 2011:441) which adds to the sometimes static understanding of theory and praxis. 
account different theologies from across the ecumenical spectrum, moving together towards loving the other.

Niemandt, writing on the developing missional contours within the DRC, notes that the DRC places enormous importance on the understanding of the context in which it operates (Niemandt 2010:95). Within the context of the Framework Document, this could be contested, because the document itself does not refer in any detail to the contextual realities faced in South Africa. Where it does address context, it tends to cite broad issues and challenges (Niemandt 2010:92-93) that are common to almost every developing nation at present. The specific South African social, political and economic context does not receive direct and detailed consideration. Taking into account the previous points made by Bosch, the importance of rigorous contextual missiology should not be underestimated in such important processes and the drafting of framework documents ${ }^{37}$. Therefore, one could conclude that the aspects of contextualisation, which Bosch argues for, are lacking in the Missional Framework Document.

It is the view of the authors that the Framework Document rather opted for a more systematic or global missiology ${ }^{38}$ which, although it is valid, cannot respond to the current contextual problems and 'signs of the times' that South Africa and South Africans face at present. Cilliers, in a paper entitled Poverty and Privilege, examines some of Beyers Naudé's sermons, and in doing so, he comments directly on the uncontextual nature of the Missional Framework Document. Cilliers (2015) notes ${ }^{39}$ :

On the whole however, only a few, very general comments are made on the calling to be missional within specific contexts, i.e. practising 'public theology' within a new understanding of the 'world' ${ }^{40}$. Although one surely should not judge a movement on the grounds of a single document, this official document in my opinion still lacks a specific analysis of urgently relevant issues in the current South African context, issues directly related to structural injustices that still prevail, even twenty years after Apartheid. With due respect: although there are a few direct references to South Africa ${ }^{41}$, this document could as well have originated in North America, or Antarctica, for that matter. (pp. 11-12)

In conclusion, although the theology of the Framework Document is a sound reflection on ecumenical missiology from a systematic point of view, the missiology of the Framework Document lacks the necessary contextualisation to be of use for both local churches and the broader

\footnotetext{
37.For further comments on the importance of contextual theology with regard to mission, see Newbigin (1995:121-159).

38.The Framework Document mentions the World Council of Church's (WCC) Busan gathering (paragraph 1.2), but not the 'Together Towards Life' document (drafted by the Busan gathering) which to an extent does argue for a theology from the margins (Paragraphs: 38-45). Regardless, within the context of the argument of this article, we would contend that the WCC is and these publications remain top-down approach which we argue is not adequate for our context.

39.This quote is part of a yet unpublished paper delivered at the University of the Western Cape summer school presented in February 2015.

40.Cilliers sites paragraph 8 from the Missional Framework Document.

41.Cilliers sites paragraphs 10 and 13 from the Framework Document.
}

DRC Synodical structure in addressing real and pressing issues at present.

\section{Voices from below}

With the current kairos facing the DRC, it is argued that solidarity with a marginalised in both current realities and the Gospel is the only adequate way in which a missional theology that resonates with the Missio Dei should be pursued. This engagement, however, cannot only happen on an academic level which itself encapsulates the power of the elite. It also has to find its way into the spaces inhabited by those whose voices are suppressed. One could ask whether the dominant middle-class identity of many DRC members is not part of the empire which excludes the most vulnerable in South Africa? Some ${ }^{42}$ have suggested that this is evident in the way in which the DRC has approached issues of reconciliation, reparation and restitution as presented by the Truth and Reconciliation Commission (TRC). It is therefore more necessary than ever to hear the suffering voices which should direct the church to participate in the Missio Dei.

Tinyiko Maluleke suggests that a central element of such an engagement is the development of a theology of restitution. The need for a theology of restitution, says Maluleke, is not because of the TRC, but in spite of it (Maluleke 2008:683). He goes further saying that a theology of restitution is needed because of the 'dire implications of neo-liberal economic policies ${ }^{43}$ that have come to shape and define the world at the dawn of the 21st century, but also because of resonance with post-colonial and post-independence political economies ${ }^{\prime 44}$ (Maluleke 2008:683). He warns that if restitution is not taken seriously, the headway made towards freedom will 'dissipate before our very own eyes' (Maluleke 2008:683). One wonders whether the current cultural and racial tensions resulting from the Rhodes Must Fall ${ }^{45}$ and Open Stellenbosch campaigns are just some of the 'dissipating headway' that Maluleke speaks about? Certainly, what cannot be denied is that there is still deep trauma because of South Africa's apartheid past. Vuyani Vellem (2015:2-5) concurs with Maluleke that modernity and its neo-liberal capitalist values violently exclude black Africans from enjoying a dignified life of equality with the white minority.

If such assertions were considered, the DRC might have developed a very different Framework Document with a stronger concern for justice and reconciliation. However, some contend that the denomination and its members are still inadvertently part and parcel of the Empire which 42.Thesnaar (2013) (in his article 'Reformed Churches struggle for justice: Lessons
learnt from their submissions before the TRC') traces the DRC's narrative in the TRC process. Thesnaar, as a member of the DRC family of churches, writes on the DRC and URCSA's engagement with the TRC. He notes the commitment of the DRC at the TRC to the processes of reconciliation, but is critical towards the DRC (and URCSA) in terms of their implementation of reconciliation processes.

43. For a contextual criticism of neo-liberalism, see Vorster (2011:14-17).

44.This view of the dangers of neo-liberal economic policies is also held in the Accra Confession adopted by the World Alliance of Reformed Churches at its 24 General Assembly in 2004 in Accra, Ghana. The confession is available at http://wcrc.ch/ accra/the-accra-confession

45.For more on these movements, see http://www.rhodesmustfall.co.za 
perpetuates a social and economic apartheid ${ }^{46}$. This being said, it must be acknowledged that the work currently being done with regard to the Belhar Confession is, and will remain, a structural journey towards justice, but excluding 'the other' from the community of equal believers in Christ remains problematic to the witness of the unity of the Church. Bowers du Toit and Nkomo (2014) express the ecclesiological complexity of this reality in relation to the Eucharist when they write:

Those within church circles who support restitution cite the Christian practice of the Eucharist, with its explicit reference to Matthew 5:23-24 (where it states that if you are at the altar and remember that your brother has something against you, you must go and be reconciled to your brother before you can offer your gift) as saying that one should not share the bread and wine until one has made restitution to those whom one has harmed (De Gruchy 2002:8). This is an incredibly challenging statement within the context of our country, where for many Christians even the reality of sharing the Eucharist with brothers and sisters across racial boundaries cannot be conceive. (p. 3)

\section{Conclusion}

On 06 May 1990, Jaap Durand delivered a message to an ecumenical audience in a time of great political and social uncertainty. His message advocates for a church that takes the lead in showing South Africa what reconciliation and justice means. This is his expectation for the church as he states it; the church is a vehicle of hope, but not hope for an 'illusionary world'. Rather Durand advocates a hope that is rooted in the Resurrection that starts with the suffering Christ (Du Toit 2014:177). For Durand, it is only a Church that suffers with the poor that can adequately articulate the hope of the coming Kingdom of God as initiated by the Resurrected One. Durand (in Du Toit 2014) states:

The church is not the vehicle of hope by turning away from the suffering, promising the poor and the needy a better tomorrow, but taking upon itself their misery and suffering. (p. 178)

The Missional Framework Document does advocate for a missional Church which takes seriously issues of justice; however, this is inadvertently done from a position of the power and privilege of its social location. It is argued above that it does not take the contextual realities as a significant departure point which confronts the South African church. As such, it is not adequately connected to the reality of the ongoing suffering of the majority of South Africans. The result is thus that the church theorises about something which it does not fully engage or understand. There is no doubt that this document will lead to more communal engagement and opportunities for the DRC to work for, and advocate for, justice. However, it is hoped that this will invite the Church to continue to develop its missional theology in solidarity with marginalised, disenfranchised and suffering 'others' in South African society.

46. With social apartheid, it is meant that although the laws of apartheid might have been dealt with, the society which remains still reflects the separation of black and white and rich and poor.

\section{Acknowledgements}

With grateful thanks to Stellenbosch University Library E-resources section for partial funding for this research project.

\section{Competing interests}

The authors declare that they have no financial or personal relationships which may have inappropriately influenced them in writing this article.

\section{Authors' contributions}

Both J.B. and D.A.F. co-conceptualised, co-researched and co-wrote the article.

\section{References}

Bonino, M.J., 1975, Doing theology in a revolutionary situation, Fortress Press, Philadelphia, PA.

Bosch, D.J., 2011, Transforming mission: Paradigm shifts in theology of mission (20th Anniversary Edition), Orbis, New York.

Bowers du Toit, N., 2012, 'Remembrance and renewal: Exploring the role of the church as an agent of welfare after 15 years of democracy', Nederduitse Gereformeerde Teologiese Tydskrif 53(suppl. 2), 205-216. https://doi.org/ 10.5952/53-0-207

Bowers du Toit, N.F. \& Nkomo, G., 2014, 'The ongoing challenge of restorative justice in South Africa: How and why wealthy suburban congregations are responding to poverty and inequality', HTS Teologiese Studies/Theological Studies 70(2), 1-8. https://doi.org/10.4102/hts.v70i2.2022

Brown, R.M. (ed.), 1990, Kairos: Three prophetic challenges to the church, William B Eerdmans Publishing Co, Grand Rapids, MI.

Cilliers, J., 2015, Poverty and privilege: Re-hearing sermons of Beyers Naudé on religion and justice, Unpublished paper delivered at the UWC Summer School: Religion and the limits of civil society, 25 February 2015, Bellville.

De Gruchy, J.W., 2002, Reconciliation: Restoring justice, Fortress Press, London.

De Gruchy, J.W., 2013, Led into mystery: Faith seeking answers in life and death, CSM Press, London.

De Gruchy, J. \& Villa-Vincencio, C. (ed.), 1983, Apartheid is a heresy, David Philip Publishers, Cape Town.

Durand, J., 2014, Jaap Durand Praat oor eenheid, versoening en geregtigheid Ed. D. du Toit, Bybelmedia, Wellington.

Dutch Reformed Church, 2013, Framework document on the missional nature and calling of the Dutch Reformed Church, viewed 12 March 2015, from http://ngkerk. org.za/wp/index.php/english/documents/missional-nature-and-calling-of-the-drchurch/

Du Toit, D. (ed.), 2014, Jaap Durand Praat oor Versoening en Geregtigheid, Bybelkor, Wellington.

Forster, D.A., 2015, 'What hope is there for South Africa? A public theological reflection on the role of the church as a bearer of hope for the future: Original research', HTS Theological Studies 71(3), 1-13.

Green, C.J. \& Dejonge, M.P. (eds.), 2013, The Bonhoeffer reader, Fortress Press, Minneapolis, MN.

Gutiérrez, G. 2000, Theology of liberation: History, politics, and salvation, Orbis Books, New York.

Institute for Justice and Reconciliation, 2014, SA reconciliation barometer: 2014 report, viewed 01 March 2015, from http://ijr.org.za/publications/pdfs/IJR\%20 SA\%20Reconciliation\%20Barometer\%20Report\%202014.pdf

Institute for Justice and Reconciliation, 2015, SA reconciliation barometer: 2015 report, viewed 01 April 2016, from http://www.ijr.org.za/publications/SARB2015.php

Lind, P., 2016, Independent (UK), viewed 30 April 2016, from http://www.independent. co.uk/news/world/africa/south-africa-facebook-post-describing-black-people-asmonkeys-ignites-debate-over-legacy-of-racism-a6820061.html

Maluleke, T.S., 2008, 'Justice in post-apartheid South Africa: Towards a theology of restitution', Verbum et Ecclesia 29(3), 681-696. https://doi.org/10.4102/ve. v29i3.36

Migliore, D.L., 2004, Faith seeking understanding: An introduction to Christian theology, second edition, Eerdmans, Grand Rapids, MI.

Newbigin, L., 1978, The open secret: Sketches for a missional theology, SPCK, London.

News24, 2012, Marikana shooting 'like Sharpeville', viewed 18 February 2016, from http://www.news24.com/SouthAfrica/News/Marikana-shooting-like-Sharpeville20120817

Niemandt, C.J.P., 2010, 'Kontoere in die Ontwikkeling van 'n Missionêre Ekklesiologie in die Nederduitse Gereformeerde Kerk - 'n Omvangryker Vierde Golf', NGTT 51(3), 92-103. 
Niemandt, C.J.P., 2014, 'Emerging missional ecclesiology in the Dutch Reformed Church in South Africa and church polity', in A.J. Janssen \& L.J. Koffeman (eds.), Protestant church polity in changing contexts. I, pp. 65-82, LitVerlag, Zurich.
P

Nolan, A., 1988, God in South Africa: The challenge of the Gospel, Eerdmans, Grand Rapids, MI.

Rieger, J., 1998, Remember the poor: The challenge to theology in the twenty-first century, Bloomsbury T\&T-Clark, London.

Rieger, J. (ed.), 2003, Opting for the margins: Postmodernity and liberation in Christian Theology, American Academy of Religion, New York.

Saayman, W., 2007, Being missionary - Being human. An overview of Dutch Reformed Mission, Cluster Publications, Pietermaritzburg.

Stackhouse, M., 1988, Apologia: Contextualization, globalization and mission in theological education, Eerdmans, Grand Rapids, MI.

Stats SA, 2014, Poverty Trends in South Africa / Statistics South Africa, viewed 26 April 2016, from http://www.statssa.gov.za/?p=2591

Swart, M. \& Rodny-Gumede, Y., 2015, 'Introduction: Considering the aftermath of Marikana', Social Dynamics 41(2), 323-326. https://doi.org/10.1080/02533952.2 015.1060684

Thesnaar, C., 2013, Reformed churches struggle for justice: Lessons learnt from thei submissions before the TRC. NGTT is now Stellenbosch Theological Journal (STJ) $54(3-4), 1-13$
United Nations General Assembly, 1990, Report of the special committee against Apartheid, p. 45, viewed 07 June 2016, from http://repository.un org/bitstream/ Apartheid, p. 45, viewed 07 June 2016, from http://repository.un.org/bitstream/
handle/11176/58805/A_44_22\%3BS_20901-EN.pdf?sequence=21\&isAllowed=y

Van Der Merwe, W.C., 2014, Met Woord en Daad in Diens van God: Die Diakonaat van die NG Kerk in Postapartheid Suid Afrika, Doctorate, Stellenbosch University, Stellenbosch.

Van Wyngaard, C., 2013, 'The church as alternative community and the struggle for liberation in the work of David Bosch', NGTT 54(3\&4), 87-97.

Vellem, V.S., 2015, 'Black Theology of liberation: A theology of life in the context of empire', Verbum et Ecclesia 36(3), 1-6. https://doi.org/10.4102/ve.v36i3.1470

Vorster, J.M., 2011, 'An ethics of hope for moral renewal in South Africa', Journal of Theology for Southern Africa 140, 4-19.

Wolterstorff, N.P., 1983, Until justice \& peace embrace, Eerdmans, Grand Rapids, MI.

Wolterstorff, N.P., 2011, Justice in love, Eerdmans, Grand Rapids, MI.

Wolterstorff, N.P., 2013, Journey towards justice: Personal encounters in the global south, Baker Academic, Grand Rapids, MI.

World Communion of Reformed Churches, 2004, The Accra Confession, viewed 04 February 2016, from http://wcrc.ch/accra/the-accra-confession

World Bank, 2014, South Africa / Data, viewed 13 April 2016, from http://data. worldbank.org/country/south-africa?view=chart 